\title{
Research and Analysis of the Sediments from Casting Furnaces and the Mechanism of its Ori- gin
}

Štefan Michna, Jaromír Cais, Lenka Michnová

Department of Technologies and Material Engineering, Faculty of Production Technology and Management, Jan Evangelista Purkyně University Ústí nad Labem, Na Okraji 1001, 400 01, Ústí nad Labem, Czech Republic. E-mail: michna@fvtm.ujep.cz, cais@fvtm.ujep.cz, michnova@fvtm.ujep.cz

Paper is focused to analysis of emerging sediment-casting furnace for the casting alloys of $\mathrm{Al}$ - Si. The aim in the analysis of of sediment is to confirm or disprove that a substantial portion of sediment are formed due to segregation of particles the wire used for refinement structure of alloys. Subsequently, on the basis of chemical analyzes of the various structural components of the sediment to determine the nature and methylene chanizmus formation of sediment. The optimal delay time at a temperature of alloying when master alloys type of AITi5B1 is 5-10 minutes. All these master alloys act almost immediately, and in most cases, their effect is not dependent on time, temperature holding time of alloying, only at some alloys (e.g. AlSi11, AlSi9Cu3) after exceeding 30 minutes of holding time smoothing effect worsening slightly. The optimal temperature of alloying coincides with the temperatures that are used in technical practice in the casting of $\mathrm{Al}-\mathrm{Si}$ alloys. After exceeding this temperature (about $\left.750 \mathrm{C}^{\circ}\right)$ represents a slight coarsening of the structure. This is caused a slight deterioration of softening effect due to formation of clusters of particles of $\mathrm{TiB}_{2}$ or leads to their segregation, which reduces the possibilities of creating of active crystallization nucleuses.

Keywords: alloying, sediments, casting furnaces, Al - Si alloy, macrostructure, microstructure, EDX analysis, TiAl3 particles, TiB2 particles

\section{References}

[1] MICHNA, Š., LUKÁČ, I., OČENÁŠEK, V., KOŘENÝ, R., DRÁPALA, J., SCHNEIDER, H., MIŠKUFOVÁ, A. a kol. (2005). Encyklopedie hliníku. Adin, Prešov, ISBN 80-89041-88-4.

[2] LUKÁČ, I., MICHNA, Š. (2001). Colour Contrast, Strukture and Defects in Aluminium and Aluminium Alloys, Velká Britanie, Cambridge international science publishing, september 2001, ISBN 18 98326-70-3

[3] MICHNA, Š., NAPRSTKOVÁ, N., LUKÁČ, I. (2011). Mechanical Properties Optimization of AlSi12CuMgNi Alloy by Heat Treatment. Metallofizika i Noveishie Teknologii, 11 / 2011, ISSN 1024-1809

[4] VAJSOVÁ, V., MICHNA, Š. (2010). Optimization of AlZn5,5Mg2,5Cu1,5 Alloy Homogenizing Annealing, Metallofizika i Noveishie Teknologii, Volume 32, No 7, July, str. 949 - 959, ISSN 1024-1809

[5] MICHNA, Š., NÁPRSTKOVÁ, N. (2012). The use of fractography in the analysis of cracking after formed workpiece blank mechanical machining from the AlCuSnBi alloy, Manufacturing Technology, December, Vol.12, No 13. ISSN 1213 - 2489

[6] SVOBODOVÁ J., CAIS J., MICHNA Š., BRU゚HA M. (2013). Research of Corrosion Propertis of Al-Si Alloys Antimony Alloyed, Manufacturing Technology, October, Vol.13, No 3. ISSN 1213 -2489

[7] MICHNA. Š., KUŚMIERCZAK, S. (2012). Praktická metalografie, vydavatel UJEP v Ústí nad Labem, tisk OPTYS spol s.r.o., 245 str., ISBN 978-80-7414-503-2

[8] VAJSOVÁ, V. (2009). Structural inhomogeneity by Al-Cu alloys casting into metal and bentonic form. Transactions of the Universities of Kořice, č.1. ISSN 1355-2334

[9] NOVÁ, I., SOLFRONK, P., NOVÁKOVÁ, I. (2011) Vliv množstvi dislokaci na tvaritelnost slitin hliniku Strojirenska technologie, XVI/2, str. 28-34, ISSN 1211-4162

[10] VAJSOVÁ, V., MICHNA, Š. (2010). Optimization of AlZn5,5Mg2,5Cu1,5 Alloy Homogenizing Annealing., Metallofizika i Noveishie Teknologii, Volume 32, No 7, July, str. 949 - 959, ISSN 1024-1809

[11]MODOLFIO, L.F. (1979). Aluminium Alloys, Structure and Properties, Butterworths, London GB.

[12] ASM Handbook (1991). Heat Treating, ASM International, USA, Vol.4, ISBN 0-87170-379-3

[13]BOLIBRUCHOVÁ, D. TILLOVÁ, E. (2005). Zlievárenské zliatiny Al-Si, ŽU v Žiline - EDIS, ISBN 80-8070485-6.

[14]MICHNA, Š., MAJRICH, P. (2012). An analysis of the Process of Melting Food Packaging and Acquiring the Aluminium Alloy, Металлург, 11, ISSN 0026 - 0827 (IMPACT) 
[15]MICHNA, S., NÁPRSTKOVÁ, N. (2012). Research into the causes cracking of aluminum alloys of Al - Cu during mechanical machining, Manufacturing Technology, vol. 12, No. 12, June, str. 47-51, ISSN 1213-2489

[16]MICHNA, Š., HONZÁTKO, R., CAIS, J. (2013). Analysis of Causes $\mathrm{Al}_{2} \mathrm{Mg}_{4}$ - Type Spinel Inclusion Formation in Low-Pressure Casting, Manufacturing Technology, October, Vol.13, No 3. ISSN 1213 -2489

[17]HONZÁTKO, R., MICHNA, Š., CAIS, J. (2013). The Influence of Porosity on Mechanical Propertis of Casts Produced from Al-Si Alloys, Manufacturing Technology, October, Vol.13, No 3. ISSN 1213 -2489 